\title{
CULTURE, CLIMATE, AND CONTRIBUTION: Career Satisfaction Among Female Faculty
}

\author{
Louise August ${ }^{\star, * *}$ and Jean Waltman*
}

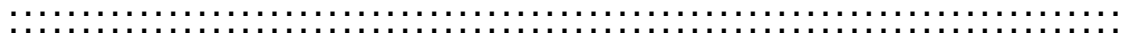

Retention of female faculty is an important issue for institutions of higher education aiming for excellence and diversity. However, an essential first step in understanding retention is to examine what contributes to career satisfaction for academic women. This study is based on data from a census survey of faculty conducted in 1996 at a Research I university located in the Midwest. Using Hagadorn's (2000) model for conceptualizing faculty job satisfaction, the study identifies domains of environmental condition, departmental climate, and demographics that play a role in female faculty's overall career satisfaction.

KEY WORDS: female faculty; career satisfaction; work climate; tenure status.

\section{INTRODUCTION}

The overall underrepresentation of women in academe, which has received considerable attention, is a complex, multifaceted problem, the result of a number of related smaller, but no less important, issues. Relative to men, women tend to be hired less frequently (Moore and Sagaria, 1993) and hired disproportionately into lower ranked positions within the institution (Harper, Baldwin, Gansneder and Chronister, 2001; Leslie, 1998). They are also more likely to be employed at less elite institutions and in the less prestigious disciplines. Women are disproportionately represented in full-time, but nontenure-track positions, of lecturer and instructor, which not only lack job security but are also among the lowest paid (Harper et al., 2001). They are tenured and promoted more slowly (Bentley and Blackburn, 1992; Moore and Sagaria, 1993), awarded tenure and promotion less often (Bain and Cummings, 2000), and paid less than their male colleagues (Nettles, Perna and Bradburn, 2000), even when controlling for other variables such as career age, rank, discipline, and institutional type (Perna, 2001).

*Center for the Education of Women, University of Michigan, Ann Arbor

**Address correspondence to: Louise August, Center for the Education of Women, University of Michigan, 330 East Liberty, Ann Arbor, MI 48104-2289. E-mail: laugust@umich.edu

177 
Further, faculty women are more likely to seek nonacademic careers (Tack and Patitu, 1992; Trower, 2000). The academic lifestyle is no longer perceived to be either as attractive or as prestigious as it once was. When compared with opportunities in other sectors, the long hours, relatively poor compensation, and the challenge of balancing one's professional and personal lives are serious issues for female faculty and female graduate students considering academic careers (Trower, 2000). To the extent that an academic life is not seen a viable choice, the supply of faculty will necessarily be curtailed.

Perhaps most troubling, women have higher rates of attrition from the academy than men both pre- and posttenure (Menges and Exum, 1983; Rausch, Ortiz, Douthitt and Reed, 1989; Rothblum, 1988). Rausch et al. (1989) and Rothblum (1988) also found the rate of voluntary departure before tenure review was more than two times greater for women than men. This suggests that the tenure process and tenure status may be an important component of satisfaction and attrition, especially for junior faculty women.

It is not enough merely to recruit and hire more women; once hired, women faculty must be retained by fostering a satisfying work environment in which they can perform well and prosper. Because satisfaction is a crucial component of retention (Johnsrud and Heck, 1994; Rausch et al., 1989), attempts to retain and advance greater numbers of women faculty members must begin with examinations of what contributes to job satisfaction for this important portion of the faculty.

In this study we examine aspects of faculty life that lead to satisfactory careers for tenured and nontenured female faculty as a necessary first step in better understanding and addressing the issue of retention. We use Hagadorn's (2000) framework for conceptualizing faculty job satisfaction to organize and interpret the data from our study.

\section{LITERATURE REVIEW}

Level of satisfaction is a key component in faculty members' "intent to leave," and moderates such other variables as salary adequacy and level of influence (Matier, 1990; Smart, 1990). In turn, the ways in which faculty members perceive the quality of their worklife have a significant impact on their satisfaction or morale (Johnsrud and Rosser, 2002). The concept of faculty worklife is very broad, encompassing a great number of variables. Johnsrud and Heck (1998) proposed a workload model that categorized aspects of worklife into three constructs: professional priorities and rewards, administrative relations and support, and quality of benefits and services. Within these three categories is a wide range of job-related issues, many of which particularly affect women faculty and that have been independently studied by higher education researchers. 
One key aspect of faculty career satisfaction is the work itself: the research, teaching, and service commitments (Olsen, Maple, and Stage, 1995). As Johnsrud and Rosser (2002) report, "Faculty members are dedicated to their work, and they love what they do" (p. 518). Important is their perceived control of their career development (Olsen et al., 1995), their high degrees of autonomy (Tack and Patitu, 1992), and the challenge they take from their work (Manger, 1999). Although women faculty members express these same high values for their intellectual lives, the level of satisfaction with their worklives can be affected by perceptions of overload. For example, in some cases women in departments with few other women feel pressured to assume heavier committee and student advising loads (Sonnert and Holton, 1995). Women also report that they are assigned heavier teaching loads (Park, 2000; Parson, Sands, and Duane, 1991; Sandler and Hall, 1986; Xie and Shauman, 1998).

Another component of satisfaction concerns how well faculty members perceive they are valued and recognized by their peers and by the institution. Feeling valued takes many forms, including receiving rewards, as well as perceiving an adequate and equitable allocation of such resources as research support, clerical and graduate student support, technology (Johnsrud and Des Jarlais, 1994), and comparable salary (Hagedorn, 1996). Faculty members also value the opportunity to have input and influence in decisions. Morale is highest when faculty members participate in governance and decisionmaking (Rice and Austin, 1988). Stress, which has been conceptualized as dissatisfaction (Barnes, Agago, and Coombs, 1998), can result from faculty members' perceptions of inadequate rewards and recognition (Gmelch, Lovrich, and Wilke, 1984; Gmelch, Wilke, and Lovrich, 1986).

Research indicates that women generally report having access to fewer resources than their male colleagues in terms of start-up equipment, financial assistance, and graduate student support (Astin, 1991; Johnsrud and Wunsch, 1991; Olsen and Sorcinelli, 1992; Park, 2000; Parson et al., 1991; Sandler and Hall, 1986). They also perceive themselves as lacking in a voice of authority among their colleagues (Aisenberg and Harrington, 1988).

A large number of researchers have also reported that a sense of community is important to satisfaction. In terms of their relationships with colleagues, women faculty members often perceive their academic departments to be challenging and chilly climates. They feel left out of male networks and feel isolated from their male colleagues. They believe that they are treated differently from their male counterparts, getting less support and approval from senior colleagues and chairpersonss and less information about tenure (Astin, 1991; Boice, 1993; Fox, 1991; Johnsrud and Wunsch, 1991; Olsen et al., 1995; Olsen and Sorcinelli, 1992; Parson et al., 1991; Riger, Stokes, Raja, and Sullivan, 1997). While both male and female junior professors can experience such unsupportive conditions, 
women appear to perceive them more pervasively (Finkelstein and LaCellePeterson, 1992; Olsen and Sorcinelli, 1992).

Mentoring, which is very often more difficult for women than for men faculty members to establish, is also an important aspect of career satisfaction. While women report that they have been able to succeed without mentoring, they also report feeling less able to work productively, less connected to their peers and to the university community, and less able to develop in multiple directions (Waltman, 2001). Satisfactory mentoring involves, among other things, having a role model for inspiration and work-related influence (Anderson and Ramey, 1990; Cullen and Luna, 1993); having someone to encourage, affirm, and instill confidence (Nye, 1997); and having a sponsor, protector, and research coach (Hall and Sandler, 1983).

Department chairpersons are an important source of mentoring, and how well a chairperson supports, interacts, and helps socialize faculty members is another aspect of satisfaction (Gmelch et al., 1984; Olsen and Crawford, 1998). Some research suggests that women tend to be less satisfied than men with their relationships with chairpersons (Smith and Plant, 1982). According to Johnsrud and Atwater (1993) a chairperson's poor relationship with the department is an aspect of worklife that results in more women than men leaving their positions.

Perceptions of equity and transparency in the tenure process are also important components of career satisfaction. In general, women appear to be more stressed about tenure (Park, 2000). Two studies (Rausch et al., 1989; Rothblum, 1988) found the rate of voluntary departure before tenure review was more than two times greater for women than men, and Rausch et al. found that women who left cited issues related to the fairness of the tenure process and clarity of tenure guidelines among their reasons for leaving. In another study, women were significantly more likely than men to cite lack of clarity of tenure criteria and review process and relations with the departmental personnel committee as barriers to their success (Johnsrud and Atwater, 1993; Johnsrud \& Des Jarlais, 1994). Other studies confirm the concern women faculty feel over tenure expectations and unclear information about tenure criteria (Austin and Rice, 1998; Menges and Exum, 1983).

Family duties also represent a challenge to women faculty members. They report that the difficulties and time constraints in balancing their professional careers with their personal and family lives are more of a problem for them than for their male colleagues and put them at a disadvantage within their departments (Aisenberg and Harrington, 1988; Parson et al., 1991; Riger et al., 1997). For example, time pressures and quality of life are aspects of worklife that result in more women than men leaving their positions (Barnes et al., 1998; Johnsrud and Heck, 1994). 


\section{CONCEPTUAL FRAMEWORK}

We use Hagedorn's "Conceptual Framework of Faculty Job Satisfaction" (2000) as the way to organize and interpret the data from our study (Table 1). The framework incorporates a number of the environmental and individual characteristics that research has shown as contributing to satisfaction for academics. Satisfaction-related variables are divided into two basic categories: mediators and triggers.

Mediators are ongoing factors that interact with each other to influence a person's level of job satisfaction. Hagedorn's framework has three types of mediators: (a) motivators and hygienes - job characteristics such as salary, level of achievement, and amount of responsibility; (b) demographics-personal characteristics of gender and ethnicity and academic characteristics of institution type and discipline; and (c) environmental conditions-relationships with colleagues, administrators, and students as well as general perceptions of climate. Triggers are major life events-such as divorce and other family occurrences, life and career stage changes, and a person's sense of work-place justice-that alter the person's response to work.

\section{METHODOLOGY}

This study utilizes data from a survey of faculty work-life conducted in 1996 at a Research I university in the Midwest. The study employed a census ap-

TABLE 1. Hagedorn's Conceptual Model of Faculty Job Satisfaction ${ }^{a}$

\begin{tabular}{|c|c|c|c|}
\hline \multicolumn{3}{|c|}{ Mediators } & Triggers \\
\hline $\begin{array}{l}\text { Motivators \& } \\
\text { Hygienes }\end{array}$ & Demographics & $\begin{array}{l}\text { Environmental } \\
\text { Conditions }\end{array}$ & Change or Transfer \\
\hline $\begin{array}{l}\text { Achievement } \\
\text { Recognition } \\
\text { Work itself } \\
\text { Responsibility } \\
\text { Advancement } \\
\text { Salary }\end{array}$ & $\begin{array}{l}\text { Gender } \\
\text { Ethnicity } \\
\text { Institutional type } \\
\text { Academic discipline }\end{array}$ & $\begin{array}{l}\text { Collegial relationships } \\
\text { Student relationships } \\
\text { Administration } \\
\text { Institutional climate or } \\
\quad \text { culture }\end{array}$ & $\begin{array}{l}\text { Change in life stage } \\
\text { Change in family-related } \\
\text { or personal } \\
\text { circumstances } \\
\text { Change in rank or tenure } \\
\text { Transfer to a new } \\
\text { institution } \\
\text { Change in perceived } \\
\text { justice } \\
\text { Change in mood or } \\
\text { emotional state }\end{array}$ \\
\hline
\end{tabular}

${ }^{a}$ From Hagedorn, 2002. 
proach to survey all university faculty who held at least half-time instructional appointments and had been at the university for at least one year. Survey data were compared to information from the university personnel database; $t$ tests conducted between respondents and nonrespondents showed no significant differences across several measures, indicating that the respondent group was fairly representative of the faculty population as a whole. The current research utilizes a subset of the data: 247 female tenured and tenure-track faculty, which had a response rate of $56 \%$. The sample is predominantly white $(87 \%)$ and clustered in the lower rank of assistant professor (45\%; Table 2). Studies of academic populations typically include too few faculty of color to conduct subanalyses that might be expected to show significant differences among nonwhite racial groups and at the same time maintain confidentiality. Our results were no different; even after collapsing all nonwhite racial and ethnic respondents into a single category, cell sizes were still insufficient to allow separate analyses by race.

Descriptive statistics and frequencies were used to examine the data. Factor analysis was conducted using principal component analysis with varimax rotation to reduce the data and produce scales sufficiently connected to thematic areas to be useful in the theoretical model. Eight scales were sufficiently connected to the thematic areas within the Hagedorn (2000) model and are presented in Table 3. We used these factors, along with single-item variables from the data set, to operationalize the theoretical constructs. The manner in which these variables are mapped onto the conceptual framework for this analysis is presented in Table 4. We were generally satisfied with the extent to which our data set was able to provide variables consistent with Hagedorn's model. However, the focus of our original inquiry and the resulting survey instrument did not measure certain constructs; these are noted in Table 4 .

Multiple regression models were designed to measure the effects of the independent variables (Table 4) in predicting the dependent variable (a single-item variable measuring faculty's self-reported overall career satisfaction, measured on a 6-point Likert scale). Variables were entered in a blockwise fashion according to the structure of the conceptual model. Demographic variables were en-

TABLE 2. Respondent Demographics

\begin{tabular}{|c|c|c|c|c|c|c|}
\hline \multirow[b]{2}{*}{ Professor } & \multicolumn{2}{|c|}{$\begin{array}{l}\text { White } \\
\text { Faculty }\end{array}$} & \multicolumn{2}{|c|}{$\begin{array}{c}\text { Faculty of } \\
\text { Color }\end{array}$} & \multicolumn{2}{|c|}{ Total } \\
\hline & 57 & $98 \%$ & 1 & $2 \%$ & 58 & $23 \%$ \\
\hline Associate professor & 67 & $86 \%$ & 11 & $14 \%$ & 78 & $32 \%$ \\
\hline Assistant professor & 92 & $83 \%$ & 19 & $17 \%$ & 111 & $45 \%$ \\
\hline Total & 216 & $87 \%$ & 31 & $13 \%$ & 247 & $100 \%$ \\
\hline
\end{tabular}


TABLE 3. Factor Loadings and Reliabilities for the Independent Variables

\begin{tabular}{|c|c|c|}
\hline & $\begin{array}{l}\text { Factor } \\
\text { Loadings }\end{array}$ & $\begin{array}{c}\text { Internal } \\
\text { Consistency } \\
\text { (alpha) }\end{array}$ \\
\hline Departmental Influence ${ }^{a}$ & & .80 \\
\hline Selecting new faculty hired in unit & .75 & \\
\hline Unit curriculum decisions & .75 & \\
\hline Selecting new graduate students & .73 & \\
\hline Affecting overall climate/culture of unit & .64 & \\
\hline Selecting the next chair of my unit & 63 & \\
\hline Selecting new faculty hired in unit & .75 & \\
\hline Quality Student Relations ${ }^{b}$ & & .77 \\
\hline Valued as a mentor/advisor by students & .78 & \\
\hline Opportunity to mentor students & .76 & \\
\hline Able to attract students to work with me & 69 & \\
\hline Valued as a teacher by students & 68 & \\
\hline Level of intellectual stimulation from student interactions & .59 & \\
\hline Freedom to decide courses taught & .45 & \\
\hline Good Relations with Department Chairperson ${ }^{b}$ & & .86 \\
\hline Quality of feedback from chairperson & .78 & \\
\hline Sense of support from chairperson & .78 & \\
\hline Quality of feedback from reviews & .73 & \\
\hline Disparate Workload & & .73 \\
\hline I am asked to serve on many committees & .74 & \\
\hline I have a larger than average number of advisees & .71 & \\
\hline Many students come to me for informal advise & .71 & \\
\hline Fair Tenure Practices ${ }^{c}$ & & .81 \\
\hline $\begin{array}{l}\text { The process and criteria used are applied consistent } \\
\text { and fairly }\end{array}$ & .86 & \\
\hline $\begin{array}{l}\text { Criteria used to reach tenure decisions are generally } \\
\text { appropriate }\end{array}$ & .81 & \\
\hline It is important to get along with the "right people"r & .78 & \\
\hline Tenure procedures are clearly defined and understood & .77 & \\
\hline $\begin{array}{l}\text { Tenure decisions depend on the quality of the work } \\
\text { produced }\end{array}$ & 68 & \\
\hline Departmental Climate ${ }^{c}$ & & .80 \\
\hline I constantly feel under scrutiny by my colleagues & .75 & \\
\hline $\begin{array}{l}\text { There are many unwritten rules concerning interaction } \\
\text { with peers }\end{array}$ & .73 & \\
\hline $\begin{array}{l}\text { It is easy to misread signals as to what one should give } \\
\text { highest priority }\end{array}$ & .72 & \\
\hline $\begin{array}{l}\text { Others seem to find it easier to learn about and fit in with } \\
\text { unwritten rules }\end{array}$ & .71 & \\
\hline
\end{tabular}


TABLE 3. (Continued)

\begin{tabular}{lll}
\hline & $\begin{array}{c}\text { Factor } \\
\text { Loadings }\end{array}$ & $\begin{array}{c}\text { Internal } \\
\text { Consistency } \\
\text { (alpha) }\end{array}$ \\
\hline I have to work very hard to be perceived as a legitimate & & \\
$\quad$ scholar & .63 & \\
I feel pressure to change my research agenda in order to fit & & .56 \\
$\quad$ in with unit priorities & & .89 \\
Having a Senior Colleague Act as a Mentor & \\
Explains unit organization and politics & .84 & \\
Protects you (re: dept. politics, etc.) & .78 \\
Advises you with respect to career decisions & .77 & \\
Understands problems/issues of balancing work and family & .70 \\
Discusses goals and issues in your discipline & .66 & \\
Helps secure resources for research, travel, etc. & .66 & \\
Serves as a role model & .57 & \\
Professional Productivity & & .79 \\
Had articles published by refereed journal & .83 & \\
\# last 2yrs: submitted articles to journals & .82 & \\
Submitted a research or grant proposal & .63 & \\
Had articles publ'd by non-refereed journal & .61 & \\
Presented paper or helped plan conference & .61 & \\
Had a chapetr published in a book & .57 & \\
\hline
\end{tabular}

${ }^{a}$ Four-point scale: Really no influence $=1$ to Substantial influence $=4$.

${ }^{b}$ Four-point scale: Not satisfied at all $=1$ to Very satisfied $=4$.

${ }^{c}$ Four-point scale: Strongly disagree $=1$ to Strongly agree $=4$.

${ }^{d}$ Five-point scale: Not at all $=1$ to To a great extent $=5$.

${ }^{e}$ Five-point scale: Never $=1$ to 10 times or more $=5$.

${ }^{r}$ These items were reversed coded for scaling the index.

tered into the model first followed by motivator and hygiene variables, environmental conditions, and triggers.

In applying the data to the model, we paid particular attention to tenure status since rates of attrition are higher for nontenured women (Rausch et al., 1989; Rothblum, 1988), and a number of satisfaction related issues affect nontenured women more pervasively (Finkelstein and LaCelle-Peterson, 1992; Olsen and Sorcinelli, 1992). Accordingly, separate regressions were performed on the entire sample of female faculty and also on tenured and nontenured women to help tease out the effect tenure status has on overall satisfaction. 
TABLE 4. Variables Used to Operationalize Hagedorn's Theoretical Constructs

Motivators and Hygienes

Achievement

Recognition

Work itself

Responsibility

Advancement

Salary

Demographics

Gender

Ethnicity

Institutional type

Environmental Conditions

Collegial relationships

Student relationships

Administration

Institutional climate or culture

Triggers

Change in rank or tenure

Transfer to a new institution Change in perceived justice

Change in life stage

Change in family-related or personal circumstances

Change in mood or emotional state
Measure of professional productivity; publications and presentations

Measures not available from the data set

Measures not available from the data set

Number of committees served on or chaired

Controlled for by use of tenure status

Single item measuring the comparability of salary with similar peers

Controlled for by use of data subset

Dichotomous variable representing white and nonwhite

Controlled for by single site study

Measure of good relationship with unit chairperson

Measure of cordial, supportive peers

Satisfaction with student relationships

Assessment that tenure process is clear, fair, equitable

Degree of faculty influence and involvement in unit

Measure of a problematic departmental climate

Recency of promotion in rank or obtaining tenure

Recency of institutional change

Measure of a disparate workload

Single items measuring salary equity, the presence of organizational

barriers, and an equitable distribution of resources

Measures not available from the data set Measures not available from the data set

Measures not available from the data set 


\section{RESULTS}

The results of the final regression models for all women faculty, tenured women, and nontenured women, are presented in Table 5, and explain 46\%, 50\%, and $40 \%$, respectively, of the variance in female faculty's overall career satisfaction. Variables at the $p<.10$ level, while not robust or significant in a statistical sense, are noted in Table 5 with a single asterisk. There is practical significance in calling out these marginally significant variables from the rest, particularly for discussion purposes in the following section.

TABLE 5. Results of the Regression Analyses

\begin{tabular}{|c|c|c|c|c|c|}
\hline \multirow[b]{3}{*}{ Independent Variables } & \multicolumn{5}{|c|}{ Overall Satisfaction } \\
\hline & \multicolumn{2}{|c|}{$\begin{array}{c}\text { All } \\
\text { Women } \\
n=247\end{array}$} & \multicolumn{2}{|c|}{$\begin{array}{l}\text { Tenured } \\
\text { Women } \\
\mathrm{n}=136\end{array}$} & $\begin{array}{l}\text { Nontenured } \\
\text { Women } \\
\mathrm{n}=111\end{array}$ \\
\hline & beta & sig & beta & sig & beta \\
\hline Race & .033 & & -.004 & & .058 \\
\hline Professional Productivity & -.039 & & .051 & & -.401 \\
\hline Responsibility & .076 & & .096 & & .067 \\
\hline Comparable Salary & .126 & $* *$ & .274 & $* * * *$ & -.007 \\
\hline Collegial Peer Relations & .094 & & .013 & & $.237 *$ \\
\hline Chairperson Relations & .189 & $* *$ & .182 & $* *$ & .143 \\
\hline Having a Mentor & .091 & $*$ & .000 & & $.128 *$ \\
\hline Student Relations & .208 & $* * * *$ & .265 & $* * * *$ & $.149 *$ \\
\hline Fair Tenure Practices & .080 & & .009 & & .128 \\
\hline Departmental Influence & .124 & $* *$ & .204 & $* * *$ & .024 \\
\hline Departmental Climate & -.206 & $* * * *$ & -.271 & $* * * *$ & $-.190 * *$ \\
\hline Recency of Promotion/Tenure & .042 & & .037 & & .080 \\
\hline Recency of Institution Change & -.037 & & -.035 & & -.038 \\
\hline Disparate Workload & -.025 & & -.133 & $*$ & .091 \\
\hline Gender Equity in Salary & .085 & & .135 & $*$ & .101 \\
\hline Organizational Barriers & -.026 & & -.002 & & -.037 \\
\hline Equitable Distribution of Resources & .034 & & .032 & & .036 \\
\hline$R^{2}$ & .499 & & .560 & & .492 \\
\hline Adjusted $R^{2}$ & .462 & & .501 & & .400 \\
\hline$F_{(\mathrm{df})}$ & $\begin{array}{c}13.422 \\
(14,246)\end{array}$ & $* * * *$ & $\begin{array}{r}9.475 \\
(13,135)\end{array}$ & $* * * *$ & $\begin{array}{l}5.307 * * * * \\
(14,110)\end{array}$ \\
\hline
\end{tabular}

$* p<.10, * * p<.05, * * * p<.01, * * * * p<.001$.

While not significant in a statistical sense, variables at the $\mathrm{p}<.10$ level are noted for their practical significance and treatment in the discussion section. 


\section{Results for All Faculty Women}

The model for all women faculty was significant $(p<.001)$ and explained $46 \%$ of the variance in overall career satisfaction, the dependent variable. Among the most significant predictors of career satisfaction for all faculty women were the variables in the environmental conditions block. These included measures of problematic departmental climate; the quality of student relationships and such related activities as mentoring and advising students $(p<.001)$; a supportive relationship with the unit chairperson; and the level of influence within the department or unit $(p<.01)$. The most significant motivator/hygiene variable was the agreement with the statement that one's salary is comparable to similar others in the unit or department $(p<.05)$. While contributing to the model as a whole, none of the trigger variables was significant.

\section{Results for Tenured Women}

The model explained 50\% $(p<.001)$ of the variance in the overall career satisfaction of tenured faculty women. As with the results for all women faculty, the most significant predictors for tenured faculty women were the variables in the environmental conditions block. The same variables were significant for these women as for women overall, although the two variables-comparable salary and the importance of departmental influence-became more significant, $p<.001$ and $p<.01$, respectively.

\section{Results for Nontenured Women}

While the model for nontenured women was significant overall $(p<.001)$ and explained $40 \%$ of the variance in overall career satisfaction, the independent variables were less significant for this subgroup. The level of influence within the department or unit was significant at the $p<.05$ level, and quality of relations with peers and students and having a mentor were only marginally significant at the $p<.10$ level.

\section{Limitations}

Although we were generally satisfied with the results of this study, the focus of our original (1996) inquiry and the resulting survey instrument were not conducive to the measurement of certain constructs; this somewhat hampered our ability to utilize fully the constructs in Hagedorn's (2000) model or to operationalize them in quite the same ways. Although we believe that our findings are overall informative, the collection of data at a single Research I university limits the generalizability of our findings to dissimilar institutions. 
We recognize that female is not a homogenous category that adequately represents the rich diversity of individuals within this category. However, the small number of female faculty of color in the study precluded analysis of faculty characteristics by racial and ethnic subgroups.

A final limitation is the use of cross-sectional data to measure perceptions of career satisfaction. In the absence of longitudinal data describing the dynamics of faculty satisfaction over time, conclusions about causality are necessarily limited. Particularly difficult to assess are changes in life and work circumstances, the so-called trigger variables. As a result, this study focuses on the relationship between the various independent variables and career satisfaction rather than suggesting causality.

\section{DISCUSSION AND CONCLUSION}

The overall regression model was significant $(p<.001)$ and explained a substantial portion of the variance $(46 \%)$ of overall career satisfaction for women faculty. A number of the independent variables that were significant in the overall model are those best supported by the literature. These include the motivator/ hygiene variable measuring the importance of a comparable salary $(p<.05)$ as well as such environmental condition variables as good relations with the department chairperson $(p<.05)$, the level of involvement and influence within the department $(p<.05)$, the importance of student relations $(p<.001)$, and the negative effect of a problematic departmental climate $(p<.001)$.

The block of trigger variables was not significant except for the measures of disparate workload and salary equity, which were significant only for tenured women and only at $p<.10$. This result is likely due to our limited ability to extract variables from the data set that matched exactly the model constructs. We were unable to measure three of the six trigger constructs (changes in life stage, family circumstances, or emotional state). Further, the survey sample was limited to faculty who had been at the university for at least one year, thus effectively eliminating from our sample the most recently arrived faculty, those most likely to be experiencing a trigger event.

The data fit the model best for tenured women, explaining 50\% of the variance as compared to $40 \%$ for untenured women. The difference between the results for these two groups is interesting. Having a salary comparable to similar peers was highly significant $(p<.001)$ for tenured women but not for the nontenured. Salary may be less important to junior faculty, who are happy to have secured tenure-track jobs at all, as compared to tenured women who have had more time to recognize possible salary discrepancies among their colleagues and themselves. While contributing to the overall significance of the models, measures of professional productivity and responsibility were not significant for either group of women.

As expected, and in keeping with the literature, having a senior colleague act 
as a mentor and role model was significant for nontenured women. The importance of mentoring may diminish somewhat over time, explaining the lack of significance to tenured women for whom being a mentor themselves may be a more important contributor to satisfaction. The quality of teaching, mentoring, and advising relationships with students was significant for both tenured and nontenured women. That such student relationships are less significant for nontenured women may reflect the relatively greater importance and priority accorded to research and publication in the pre-tenure years.

Being involved and influential in department matters was significant $(p<.01)$ only for tenured women, perhaps suggesting that only with the passage of time and the attainment of tenure do faculty members become less self-focused and more directed toward becoming influential among their colleagues.

Conversely, collegial peer relations was significant only for nontenured women. This finding may suggest that, by the time faculty achieve tenure, they have found their niche and are more able than their junior colleagues to understand and adapt to the idiosyncrasies of their fellow department members. In other words, tenured faculty may have figured out the "lay of the land" and thus are less sensitive to the intricacies of peer relationships.

We might liken the early experiences of newly hired women faculty to being thrown into the deep end of the pool. They are so overwhelmed by the requirements and responsibilities of their new positions that it may be a few years before they are able to get their heads above water and take notice of the details of their surroundings. This may explain why variables such as comparable salary, departmental influence, and the perceived justice measures were more significant for tenured women.

Possibly our most surprising findings were that, contrary to the literature, neither chairperson relations nor fair tenure practices were significant to nontenured women. Perhaps limitations in the way we were able to operationalize these constructs failed to capture their salience for this group of women.

The results of this study provide needed insight into understanding how the components of career satisfaction may differ as a function of tenure status. The category of "female faculty" is by no means a homogenous one; issues salient to nontenured junior faculty are likely to change and evolve once tenure is attained. Understanding what makes for a satisfying career for each of the tenure-track ranks will help to guide institutions of higher education in their efforts to create diverse campus environments and welcoming, supportive climates that allow female faculty to succeed and thrive.

\section{IMPLICATIONS FOR FUTURE RESEARCH}

Differences in model results for tenured and nontenured faculty women suggest that the data fits the model best for tenured women. Accordingly, the tenured women subgroup should be disaggregated to examine separately how well 
associate and full professors fit the model to understand how these two groups differ or are similar. Because certain variables that we expected to be significant were not, it may be useful to construct separate models for the tenured vs. nontenured groups. Finally, we plan an expansion of the study's theoretical base to include certain constructs suggested by the literature but not encompassed by Hagedorn's model, such as work/family balance, role clarity and conflict, and externalities.

\section{REFERENCES}

Aisenberg, N., and Harrington, M. (1988). Women of Academe: Outsiders in the Sacred Grove, Amherst, The University of Massachusetts Press.

Anderson, R. T., and Ramey, P. (1990). An exploration of attributes present in a mentor/ protégé relationship in nursing education administration. In: Welch, L. B. (ed.), Women in Higher Education: Changes and Challenges, Praeger, New York, pp. 199208.

Astin, H. (1991). Citation classics: Women's and men's perceptions of their contributions to science. In: Zuckerman, H., Cole, J. R., and Bruer, J. T. (eds.), The Outer Circle: Women in the Scientific Community, W. W. Norton and Co., New York, pp. 57-70.

Austin, A. E., and Rice, R. E. (1998). Making tenure viable: Listening to early career faculty. American Behavioral Scientist 41(5): 736-754.

Bain, O., and Cummings, W. (2000). Institutional barriers to the career advancement of academic women. Comparative Education 44(4): 493-514.

Barnes, L. L. B., Agago, M. O., and Coombs, W. T. (1998). Effects of job-related stress on faculty intention to leave academia. Research in Higher Education 39: 457-469.

Bentley, R. J., and Blackburn, R. (1992). Two decades of gains for female faculty? Teachers College Record 93(4): 697-709.

Boice, R. (1993). Early turning points in professorial careers of women and minorities. In: Gainen, J., and Boice, R. (eds.), Building a Diverse Faculty, New Directions for Teaching and Learning, No. 53, Jossey-Bass, San Francisco, pp. 71-79.

Cullen, D. L., and Luna, G. (1993). Women mentoring women in academe: Addressing the gender gap in higher education. Gender and Education 5(2): 125-137.

Finkelstein, M. J., and LaCelle-Peterson, M. W. (1992). New and junior faculty: A review of the literature. In: Sorcinelli, M. D., and Austin, A. E. (eds.), Developing New and Junior Faculty, New Directions for Teaching and Learning, No. 50, Jossey-Bass, San Francisco, pp. 5-14.

Fox, M. F. (1991). Gender, environmental milieu, and productivity in science. In: Zuckerman, H., Cole, J. R., and Bruer, J. T. (eds.), The Outer Circle: Women in the Scientific Community, W. W. Norton and Co., New York, pp. 188-204.

Gmelch, W. H., Lovrich, N. P., and Wilke, P. K. (1984). Sources of stress in academe: A national perspective. Research in Higher Education 20: 477-490.

Gmelch, W. H., Wilke, P. K., and Lovrich, N. P. (1986). Dimensions of stress among university faculty: Factor-analytic results from a national study. Research in Higher Education 24: 266-286.

Hagedorn, L. S. (1996). Wage equity and female faculty job satisfaction: The role of wage differentials in a job satisfaction causal model. Research in Higher Education 37: 569-598. 
Hagedorn, L. S. (2000). Conceptualizing faculty job satisfaction: components, theories, and outcomes. New Directions for Institutional Research 27(1): 5-20.

Hall, R. M., and Sandler, B. R. (1983). Academic Mentoring for Women Students and Faculty: A New Look at an Old Way to Get Ahead, Project on the Status and Education of Women, Association of American Colleges, Washington, DC.

Harper, E. P., Baldwin, R. G., Gansneder, B. G., and Chronister, J. L. (2001). Full-time women faculty off the tenure track: Profile and practice. Review of Higher Education 24(3): 237-257.

Johnsrud, L. K., and Atwater, C. D. (1993). Scaffolding the ivory tower: Building supports for new faculty to the academy. CUPA Journal 44(1): 1-14.

Johnsrud, L. K., and Des Jarlais, C. D. (1994). Barriers to the retention and tenure of women and minorities: The case of a university's faculty. Review of Higher Education 17: $335-353$.

Johnsrud, L. K., and Heck, R. H. (1994). A university's faculty: Predicting those who will stay and those who leave. Journal for Higher Education Management 10(1): 71-84.

Johnsrud, L. K., and Heck, R. H. (1998). Faculty worklife: Establishing benchmarks across groups. Journal of Higher Education 39(5): 539-555.

Johnsrud, L. K., and Rosser, V. (2002). Faculty members' morale and their intention to leave. Journal of Higher Education 73(4): 518-542.

Johnsrud, L. K., and Wunsch, M. (1991). Junior and senior faculty women: Commonalities and differences in perceptions of academic life. Psychological Reports 69: 879886.

Leslie, D. M. (ed.) (1998). The Growing Use of Part-Time Faculty: Understanding Causes and Effects (Vol. 104), Jossey-Bass, San Francisco.

Manger, D. K. (1999, September 3). The graying professoriate. Chronicle of Higher Education p. A18.

Matier, M. W. (1990). Retaining faculty: A tale of two campuses. Research in Higher Education 31: 39-60.

Menges, R. J., and Exum, W. H. (1983). Barriers to the progress of women and minority faculty. Journal of Higher Education 54(2): 123-144.

Moore, K. M., and Sagaria, M. A. (1993). The situation of women in research universities in the United States: Within the inner circles of academic power. In Glazer, J. S., Bensimon, E. M., and. Townsend, B. K. (eds.), Women in Higher Education: A Feminist's Perspective, Ginn Press, Needham Heights, MA, pp. 227-240.

Nettles, M. T., Perna, L. W., and Bradburn, E. M. (2000). Salary, Promotion, and Tenure Status of Minority and Women Faculty in U.S. Colleges and Universities, NCES, Washington, DC.

Nye, G. T. (1997). Academic Discipline, Mentoring, and the Career Commitment of Women Faculty. Doctoral Dissertation, Louisiana State University. (Dissertation Abstracts International, 09A:3441)

Olsen, D., and Crawford, L. A. (1998). A five-year study of junior faculty expectations about their work. Review of Higher Education 22(1): 39-54.

Olsen, D., Maple, S., and Stage, F. (1995). Women and minority job satisfaction: Professional role interests, professional satisfactions, and institutional fit. Journal of Higher Education 66(3): 267-293.

Olsen, D., and Sorcinelli, M. D. (1992). The pretenure years: A longitudinal perspective. In: Sorcinelli, M.D., and Austin, A. E. (eds.), Developing New and Junior Faculty, New Directions for Teaching and Learning, No. 50, Jossey-Bass, San Francisco, pp. $15-25$. 
Park, S. M. (2000). Research, teaching, and service: Why shouldn't women's work count? In Ropers-Huilman, B. (ed.), Women in Higher Education: A Feminist Perspective (2nd Ed.), Pearson Custom Publishing, Boston, pp. 285-308.

Parson, L. A., Sands, R. G., and Duane, J. (1991). The campus climate for women faculty at a public university. Initiatives 54(1): 19-27.

Perna, L. (2001). Sex differences in faculty salaries: A cohort analysis. Review of Higher Education 21(4): 315-342.

Rausch, D. K., Ortiz, B. P., Douthitt, R. A., and Reed, L. L. (1989). The academic revolving door: Why do women get caught? CUPA Journal 40(1): 1-16.

Rice, E. R., and Austin, A. E. (1988). Faculty morale: What exemplary colleges do right. Change 20(2): 51-58.

Riger, S., Stokes, J., Raja, S., and Sullivan, M. (1997). Measuring perceptions of the work environment for female faculty. The Review of Higher Education 21(1): 63-78.

Rothblum, E. D. (1988). Leaving the ivory tower: Factors contributing to women's voluntary resignation from academia. Frontiers 10(2): 14-17.

Sandler, B. R., and Hall, R. M. (1986). The Campus Climate Revisited: Chilly for Women Faculty, Administrators, and Graduate Students, Project on the Status and Education of Women, Association of American Colleges, Washington, DC.

Smart, J. C. (1990). A causal model of faculty turnover intentions. Research in Higher Education 31: 405-424.

Smith, D. B., and Plant, W. T. (1982). Sex differences in the job satisfaction of university professors. Journal of Applied Psychology 67(2): 249-251.

Sonnert, G., and Holton, G. (1995). Gender Differences in Science Careers; The Project Access Study, Rutgers University Press, New Brunswick, NJ.

Tack, M. W., and Patitu, C. L. (1992). Faculty Job Satisfaction: Women and Minorities in Peril (EDO-HE-92-4), ERIC Clearinghouse on Higher Education, Washington, DC.

Trower, C. A. (2000). Reluctantly, your faculty. Trusteeship 8(4): 8-12.

Waltman, J. A. (2001). Mentoring and Academic Success for Women Faculty Members at Research Universities. Doctoral dissertation, University of Michigan. (Dissertation Abstracts International, UMI: 3001063)

Xie, Y., and Shauman, K. (1998). Sex differences in research productivity: New evidence about an old puzzle. American Sociological Review 63(6): 847-870. 